\title{
Effect of Fertilization on Growth of Poplar Clones in Nursery
}

\author{
Gurparteek Singh, Tarsem Singh and Avtar Singh*
}

Dept. of Forestry and Natural Resources, Punjab Agricultural University, Ludhiana, Punjab (141 004), India

\section{Corresponding Author}

Avtar Singh

e-mail: avtar3@pau.edu

\author{
Article History \\ Article ID: AR1928 \\ Received in $18^{\text {th }}$ November, 2018 \\ Received in revised form $25^{\text {th }}$ February, 2019 \\ Accepted in final form $28^{\text {th }}$ February, 2019
}

\begin{abstract}
The effect of N, P and K fertilizer treatments was observed on poplar plants in nursery. The nutrients applied in combination to poplar had significant effect on height and collar diameter of entire transplants of poplar (ETP'S) produced in nursery. The nutrient treatment $\mathrm{N}_{225} \mathrm{P}_{150} \mathrm{~K}_{75}$ was effective to increase in plant height, collar diameter, average leaf area and biomass of ETP's produced. Among different clones studied clone no. L-47/48 and PL-6 attained maximum height, collar diameter, average leaf area and biomass. The minimum height was recorded in clone PL-1 and Collar diameter in clone PL-2. The average leaf area varied differently in the nine clones studied in the present investigation. The nutrient applied had significant effect on average leaf area of poplar in nursery. The maximum leaf area was recorded with the application of $\mathrm{N}_{150} \mathrm{P}_{100} \mathrm{~K}_{50}$. The biomass produced by the poplar clones under the influence of nutrient applied to Poplar clones in nursery had similar response as to average leaf area. The interaction effect (clonexnutrients) shows that each clone has differential response to nutrient applied in different combinations of $\mathrm{N}, \mathrm{P}$ and $\mathrm{K}$ treatment $\left(\mathrm{N}_{0} \mathrm{P}_{0} \mathrm{~K}_{0}\right),\left(\mathrm{N}_{75} \mathrm{P}_{50} \mathrm{~K}_{25}\right),\left(\mathrm{N}_{150} \mathrm{P}_{100} \mathrm{~K}_{50}\right)$ and $\left(\mathrm{N}_{225} \mathrm{P}_{150} \mathrm{~K}_{75}\right)$ for plant height, collar diameter, average leaf area and biomass growth. This interaction effect is reflection of genetic potential of clones under favourable G×E interaction.
\end{abstract}

Keywords: Fertilization, height, collar diameter, leaf area, clones, nursery

\section{Introduction}

Populus deltoides Bartr ex. Marsh is a one of the commercial agroforestry tree species grown in India, owing to its multiple industrial uses, fast growth, short rotation and suitability for agroforestry (Jones and Lal, 1989), this species has been extensively adopted by the farmers. The farmers grow this species on farmlands along with agricultural crops as boundary or block plantation. The cultivation of poplar has generated huge employment in the rural sector in India and has overall improved the rural economy (Chandra et al., 2011). The benefits of poplar cultivation which has also created a wood industry providing cheaper products to consumers, and reducing India's wood import. Along with clonal eucalypts, poplars are seen as the 'green gold' in the countryside (Raina et al. (2011). Poplars are used for solid wood, pulp and plywood production. Poplar based agroforestry has been found to give better economic returns than sole annual crops. Net photosynthesis, stomatal conductance and transpiration in two crops viz, turmeric (Curcuma longa L.) and moong (Vigna radiata $\mathrm{L}$.) were higher in open areas than in shade under poplar based agrihortisilviculture system. Agronomic crops showed initially better performance under partial shade in yield and yield contributing parameters, and decreased as poplar canopy advanced in age. To minimize resource competition and improve physiological processes of crops, canopy management is essential to ensure better yield under poplar based agri-horti-silviculture system (Chauhan et al., 2013). Growth increment of poplar was significantly higher when planted with fruit crops as compared to sole poplar planting. In Punjab, poplar is reliable option for agroforestry. Profits to the tune of $38.8 \%$ and $100.9 \%$ of investments are reported from rising of nursery stock within one year. Benefit: cost ratio of 1.92:1 and 2.13:1 has been estimated with pure poplar and with poplar+intercropping in a pay-back period of 7 years (Dhillon et al., 2001).

The yield of clone G-3, which once used to be the most popular clone, is declining due to attack by leaf blight disease. This clone is giving way to other clones, e.g., S7C8, Uday, L-34/82 etc. Individual plantations are, however, monoclonal (Kumar et al., 1999). Luna et al. (2011) reported that clone WSL - 39 achieved the best growth and maximum volume in Punjab, attaining diameter of $14.74 \mathrm{~cm}$; height $14.42 \mathrm{~m}$ and volume $0.1040 \mathrm{~m}^{3} /$ tree. This clone outperformed the clones for growth and volume since the beginning. The volume production of clone Udai was at par with WSL-39 at 2 and 3 years of age in Punjab. However, intensive cultivation of extensively 
followed traditional paddy-wheat rotation is creating many complications in the agro-ecosystem of the state as it has resulted in lowering the ground water table, development of compact sub-soil layer and nutrient imbalance, and is thus no longer ecologically sustainable although economically profitable. The situation is at an alarming stage, which calls for a need to diversify rotation with superior profit through sustainable land use system while maintaining the status as well as increasing the production of agricultural crops in the state as well as in country.

Availability of macro-nutrients $(\mathrm{N}, \mathrm{P}, \mathrm{K})$ and organic carbon was determined at different depths of soil and a decrease in availability of nutrients with increasing depth was recorded (Dhillon et al., 2012). Han et al. (2016) reported that the NPK chemical fertilizer decreased the soil $\mathrm{pH}$ and exchangeable calcium concentration, did not affect the soil concentrations of nitrogen and magnesium and increased the concentrations of available phosphorus and exchangeable potassium. Fertilization treatments increased the seedling height and root collar diameter by $21 \%$ and $29 \%$, respectively and the mean dry weight of the stems and a leaf by $72 \%$ and $123 \%$, respectively; but a synergistic effect of the organic manure and NPK fertilizer were not observed. Application of organic and inorganic fertilizers produced significantly higher fresh and dry weight of shoot and root and total biomass. The performances of growth were influenced significantly by $\mathrm{N}, \mathrm{P}$ and $\mathrm{K}$ at different levels in Poplar (Saravanakumar and Shanthinipriya, 2017). The application of fertilizers about $20 \mathrm{~cm}$ from the poplar cuttings enhanced growth compared to untreated cuttings and was about twice as effective as banding of fertilizers (Van den Driessche, 1999). Similarly, the application of fertilizers applied to the base of a planted tree positively influenced its growth (Bilodeau-Gauthier, 2011). Since poplars are sensitive to competing vegetation (Fang and Badong, 2008) and fertilizing whole areas increases the growth of competing vegetation also. Durai et al. (2009) emphasized that the deliberately planted trees for enhanced economic gains will certainly exploit more natural resources including inherent nutrients of soil profile as compared to sole crop. Effect of fertilization on poplars during its growing phase applied as single nutrient in nursery has been known to be positive. However, detail of appropriate nutrient combinations and specific amounts vary according to soil type and clones responses to fertilization are not known. Therefore, the present study was conducted to assess the affect of NPK in combination on the growth of Poplar in nursery.

\section{Materials and Methods}

An experiment was conducted during the year 2015-16 and data on plant parameters were recorded during 2016. The texture and initial status of the soil was viz., Silty loam in texture, having $\mathrm{pH} 7.4$, EC 0. 52, O.C. $0.45 \%$, available $\mathrm{N}$ $180 \mathrm{~kg} \mathrm{ha}^{-1}$ and $\mathrm{P} 10 \mathrm{~kg} \mathrm{ha}^{-1}$ and $\mathrm{K} 298 \mathrm{~kg} \mathrm{ha}^{-1}$. Treatments consist Nine genotypes viz. PL-1, PL-2, PL-3, PL-4, PL-5, PL-6,
PL-7, L-47/88, L- 48/89 and Four combinations of $N, P$ and $K$ applied as treatment viz, $\left(\mathrm{N}_{0} \mathrm{P}_{0} \mathrm{~K}_{0}\right),\left(\mathrm{N}_{75} \mathrm{P}_{50} \mathrm{~K}_{25}\right),\left(\mathrm{N}_{150} \mathrm{P}_{100} \mathrm{~K}_{50}\right)$ and $\left(\mathrm{N}_{225} \mathrm{P}_{150} \mathrm{~K}_{75}\right)$ with three replications were planted in the fields of department of Forestry and Natural Resources, Punjab Agricultural University, Ludhiana. The study site is situated at an elevation of 244 masl with a latitude of $30^{\circ} 56^{\prime}$ North and longitude of $75^{\circ} 52^{\prime}$ East. May and June were the hottest months whereas; December and January are the coldest. Frost occurrence is not common. On an average site received 704 $\mathrm{mm}$ rainfall, which is not evenly distributed and most of it i.e. $75-80 \%$ is receives during July and September. Three plants of each clone from each treatment were selected randomly. Further from each plant fully expanded leaves $\left(5^{\text {th }}\right.$ or $6^{\text {th }}$ leave from tip) were selected during of September and leaf area measurement was done by using portable leaf area meter (CID 110, CID INC, USA). The data was analyzed statistically two factor factorial design for the assessment of analysis of variance for morphological characters and plant nutrient analysis (Panse and Sukhatme, 1989). Data was analyzed with OPSTAT software.

\section{Results and Discussion}

The data presented in Table 1 related to plant height and collar diameter of poplar clones respectively, revealed that nutrients in different doses had significant effect on poplar growth plant height and collar diameter. Different recommended clones under study were recorded to be significant due to genotypes and their interaction effect with nutrients also recorded as significant (Table 1 and 2). The interaction effect shows that each clone has differential response for height and collar diameter growth to nutrient applied. Data reveals that among the nutrients maximum mean plant height $4.88 \mathrm{~m}$ was recorded in treatment $\left(\mathrm{N}_{225} \mathrm{P}_{150} \mathrm{~K}_{75}\right)$ followed by $\left(\mathrm{N}_{75} \mathrm{P}_{50} \mathrm{~K}_{25}\right)$ $4.84 \mathrm{~m}$ and the lowest mean height $4.56 \mathrm{~m}$ was recorded in control $\left(\mathrm{N}_{0} \mathrm{P}_{0} \mathrm{~K}_{0}\right)$. Among the clones the maximum mean height $(5.42 \mathrm{~m})$ was recorded in clone L-47/48 followed by clone PL-6 (5.25 m) and lowest mean height $4.12 \mathrm{~m}$ was recorded in PL-1 and the interaction between nutrient and clone was also found significant. Maximum plant height (5.62 $\mathrm{m}$ ) was recorded in interaction between and clone L-47/48 and minimum plant height $(3.62 \mathrm{~m})$ was recorded in interaction between and clone PL-1.

However, maximum mean collar diameter $2.59 \mathrm{~cm}$ was recorded in treatment $\left(\mathrm{N}_{225} \mathrm{P}_{150} \mathrm{~K}_{75}\right)$ followed by $\left(\mathrm{N}_{150} \mathrm{P}_{100} \mathrm{~K}_{50}\right)$ $2.55 \mathrm{~cm}$ and the minimum mean collar diameter $2.53 \mathrm{~cm}$ was recorded in $\left(\mathrm{N}_{75} \mathrm{P}_{50} \mathrm{~K}_{25}\right)$. Among the clones the maximum mean collar diameter was recorded in clone L-47/48 (2.78) followed by clone PL-6 $(2.76 \mathrm{~cm})$ and minimum mean collar diameter was recorded in PL-2 $(2.31 \mathrm{~cm})$ and the interaction between nutrient and clone was also found significant. Maximum collar diameter $2.92 \mathrm{~cm}$ was recorded in interaction between $\left(\mathrm{N}_{150} \mathrm{P}_{100} \mathrm{~K}_{50}\right)$ and clone $\mathrm{L}-47 / 48$ and minimum collar diameter $2.22 \mathrm{cmw}$ as recorded in interaction between $\left(\mathrm{N}_{225} \mathrm{P}_{150} \mathrm{~K}_{75}\right)$ and clone PL-2 (Table 1). Baker and Randal (1975) reported 


\begin{tabular}{|c|c|c|c|c|c|c|c|c|c|c|}
\hline \multirow[t]{3}{*}{ Clone } & \multirow{2}{*}{\multicolumn{4}{|c|}{$\begin{array}{l}\text { Plant height (m) } \\
\text { Nutrients (kg ha-1) }\end{array}$}} & \multirow[t]{3}{*}{ Mean } & \multirow{2}{*}{\multicolumn{4}{|c|}{$\begin{array}{c}\text { Collar diameter }(\mathrm{cm}) \\
\text { Nutrients }\left(\mathrm{kg} \mathrm{ha}^{-1}\right)\end{array}$}} & \multirow{3}{*}{$\begin{array}{l}\text { Mean } \\
\text { Mean }\end{array}$} \\
\hline & & & & & & & & & & \\
\hline & $\left(\mathrm{N}_{0} \mathrm{P}_{0} \mathrm{~K}_{0}\right)$ & $\left(\mathrm{N}_{75} \mathrm{P}_{50} \mathrm{~K}_{25}\right)$ & $\left(\mathrm{N}_{150} \mathrm{P}_{100} \mathrm{~K}_{50}\right)$ & $\left(\mathrm{N}_{225} \mathrm{P}_{150} \mathrm{~K}_{75}\right)$ & & $\left(\mathrm{N}_{0} \mathrm{P}_{0} \mathrm{~K}_{0}\right)$ & $\left(\mathrm{N}_{75} \mathrm{P}_{50} \mathrm{~K}_{25}\right)$ & $\left(\mathrm{N}_{150} \mathrm{P}_{100} \mathrm{~K}_{50}\right)$ & $\left(\mathrm{N}_{225} \mathrm{P}_{150} \mathrm{~K}_{75}\right)$ & \\
\hline PL-1 & 3.71 & 4.62 & 3.62 & 4.54 & 4.12 & 2.38 & 2.26 & 2.47 & 2.47 & 2.36 \\
\hline PL-2 & 4.05 & 4.10 & 4.38 & 3.95 & 4.12 & 2.26 & 2.33 & 2.42 & 2.22 & 2.31 \\
\hline PL-3 & 4.05 & 4.41 & 4.69 & 4.69 & 4.46 & 2.23 & 2.44 & 2.34 & 2.56 & 2.39 \\
\hline PL-4 & 5.25 & 4.55 & 4.56 & 4.93 & 4.82 & 2.58 & 2.41 & 2.46 & 2.54 & 2.50 \\
\hline PL-5 & 4.53 & 4.56 & 4.99 & 5.35 & 4.86 & 2.35 & 2.36 & 2.72 & 2.65 & 2.52 \\
\hline PL-6 & 5.32 & 5.56 & 5.05 & 5.08 & 5.25 & 2.74 & 2.88 & 2.69 & 2.74 & 2.76 \\
\hline PL-7 & 5.22 & 5.07 & 5.06 & 5.04 & 5.10 & 2.81 & 2.49 & 2.52 & 2.78 & 2.65 \\
\hline L-47/88 & 5.46 & 5.46 & 5.62 & 5.13 & 5.42 & 2.71 & 2.73 & 2.92 & 2.74 & 2.78 \\
\hline L-48/89 & 5.21 & 5.25 & 5.14 & 5.16 & 5.19 & 2.77 & 2.85 & 2.56 & 2.59 & 2.69 \\
\hline Mean & 4.56 & 4.84 & 4.79 & 4.88 & & 2.54 & 2.53 & 2.55 & 2.59 & \\
\hline \multirow{2}{*}{\multicolumn{2}{|c|}{$C D(p=0.05)$}} & Nutrients & 0.019 & & & & $\mathrm{CD}(p=0.05$ & Nutrients & 0.02 & \\
\hline & & Clones & 0.024 & & & & & Clones & 0.03 & \\
\hline \multicolumn{3}{|c|}{ Nutrients $\times$ Clones } & 0.058 & & & & Nutrie & nts $\times$ Clones & 0.05 & \\
\hline
\end{tabular}

Table 2: Effect of different doses of N, P \& K on average leaf area and above ground biomass of different Poplar in nursery

\begin{tabular}{|c|c|c|c|c|c|c|c|c|c|c|}
\hline \multirow[t]{3}{*}{ Clone } & \multicolumn{4}{|c|}{ Average leaf area $\left(\mathrm{cm}^{2}\right)$} & \multirow[t]{3}{*}{ Mean } & \multicolumn{4}{|c|}{ Above ground biomass (kg plant ${ }^{-1}$ ) } & \multirow{3}{*}{$\begin{array}{l}\text { Mean } \\
\text { Mean }\end{array}$} \\
\hline & \multicolumn{4}{|c|}{ Nutrients $\left(\mathrm{kg} \mathrm{ha}^{-1}\right)$} & & \multicolumn{4}{|c|}{ Nutrients $\left(\mathrm{kg} \mathrm{ha}^{-1}\right)$} & \\
\hline & $\left(\mathrm{N}_{0} \mathrm{P}_{0} \mathrm{~K}_{0}\right)$ & $\left(\mathrm{N}_{75} \mathrm{P}_{50} \mathrm{~K}_{25}\right)$ & $\left(\mathrm{N}_{150} \mathrm{P}_{100} \mathrm{~K}_{50}\right)$ & $\left(\mathrm{N}_{225} \mathrm{P}_{150} \mathrm{~K}_{75}\right)$ & & $\left(\mathrm{N}_{0} \mathrm{P}_{0} \mathrm{~K}_{0}\right)$ & $\left(\mathrm{N}_{75} \mathrm{P}_{50} \mathrm{~K}_{25}\right)$ & $\left(\mathrm{N}_{150} \mathrm{P}_{100} \mathrm{~K}_{50}\right)$ & $\left(\mathrm{N}_{225} \mathrm{P}_{150} \mathrm{~K}_{75}\right)$ & \\
\hline PL-1 & 369.27 & 318.34 & 419.28 & 377.33 & 371.06 & 2.72 & 2.65 & 2.68 & 3.20 & 2.81 \\
\hline PL-2 & 298.42 & 355.78 & 321.08 & 353.39 & 332.16 & 2.96 & 3.03 & 3.10 & 2.84 & 2.98 \\
\hline PL-3 & 350.33 & 382.46 & 331.77 & 365.58 & 357.53 & 2.88 & 2.91 & 2.78 & 2.82 & 2.85 \\
\hline PL-4 & 389.57 & 311.89 & 370.23 & 359.61 & 357.82 & 3.42 & 3.10 & 3.18 & 3.29 & 3.25 \\
\hline PL-5 & 375.47 & 368.95 & 388.28 & 341.99 & 368.67 & 2.98 & 3.02 & 3.12 & 2.93 & 3.01 \\
\hline PL-6 & 371.13 & 401.22 & 334.30 & 375.91 & 370.64 & 2.99 & 3.65 & 3.25 & 3.33 & 3.31 \\
\hline PL-7 & 382.31 & 382.01 & 377.06 & 394.30 & 383.92 & 3.42 & 3.18 & 3.21 & 3.19 & 3.25 \\
\hline L-47/88 & 345.47 & 377.09 & 405.39 & 339.75 & 366.92 & 3.02 & 3.09 & 3.77 & 3.32 & 3.30 \\
\hline L-48/89 & 379.29 & 396.22 & 382.52 & 378.25 & 384.07 & 3.41 & 3.51 & 3.25 & 3.29 & 3.37 \\
\hline Mean & 362.36 & 365.99 & 369.99 & 365.12 & & 3.09 & 3.13 & 3.15 & 3.13 & \\
\hline \multirow[t]{3}{*}{$\mathrm{CD}(p=0.0$} & & Nutrients & 0.019 & & & & $\mathrm{CD}(p=0.05)$ & Nutrients & 0.01 & \\
\hline & & Clones & 16.60 & & & & & Clones & 0.02 & \\
\hline & Vutrients> & $\times$ Clones & 31.66 & & & & Nutrier & nts $\times$ Clones & 0.03 & \\
\hline
\end{tabular}

that fertilization would not affect all poplar clones in the same way, so nutrient additions should be tailored to clonal requirement. Martin and Cater (1967) reported that height of Populus deltoides increased with higher fertilization doses of NPK. Nitrogen is known to increase the height of poplar clones (Nakos, 1979). Application of NPK fertilization has also reported to increase plant height in different poplar species by Jobling (1960), Satoo (1960), Blackmon and White (1972), Chen (1974), Denev (1974); Liani (1978). Clonal variation in plant height in poplar has been reported by several workers (Sidhu, 1994, 1996, Singh and Negi, 1996, Thakur et al., 1998). Gangoo et al. (1997) also reported increase in collar diameter in Populus deltoides with the application of $150 \mathrm{~kg} \mathrm{~N} \mathrm{ha}^{-1}$ and $120 \mathrm{~kg} \mathrm{P}_{2} \mathrm{O}_{5}$ ha $^{-1}$ and $10 \mathrm{t}$ manure ha- ${ }^{-1}$. Singh (2001) reported a significant increase in mean collar diameter with increasing levels of nutrients up to $\mathrm{N}_{100} \mathrm{P}_{50} \mathrm{~K}_{25}$. Isaiah (2013) reported that height and girth of Moringa were best supported by increased doses up to $120 \mathrm{~kg} \mathrm{ha}^{-1}$ of N:P:K (15:15:15) fertilizers. 
Similar response in Populus deltoides has also been reported by Brar and Katoch (1980), Deol (1982). Saravanakumar and Shantinipriya (2017) reported that the growth performance was influenced by NPK Levels significantly in Populus deltoides. Clonal variation in collar diameter of poplar has been reported by Nelson and Tauer (1987) Sidhu (1996) in Populus deltoides. Similar results have been drawn by Satoo (1960), Blackmon (1977), Brar and katoch (1980) Gangoo et al. (1997) in poplar, Bhardwaj et al. (1986) in Bauhinia variegate and Shivaprakash et al. (2000) in mulberry.

The data presented in Table 2 revealed average leaf area of poplar clones in the month of September revealed that nutrients in different doses showed non-significant effect on poplar growth (average leaf area). Different recommended clones under study were recorded to be significant due to genotypes and their interaction effect with nutrients also recorded as significant. Barigah et al., 1994 also reported that average leaf area of five poplar clones differed significantly due to their genotypes and related to higher biomass production in clones with higher average leaf area. The interaction effect shows that each clone has differential response to nutrient supplied in different combinations of $\mathrm{N}, \mathrm{P}$ and $\mathrm{K}$ treatment $\left(\mathrm{N}_{0} \mathrm{P}_{0} \mathrm{~K}_{0}\right),\left(\mathrm{N}_{75} \mathrm{P}_{50} \mathrm{~K}_{25}\right),\left(\mathrm{N}_{150} \mathrm{P}_{100} \mathrm{~K}_{50}\right)$ and $\left(\mathrm{N}_{225} \mathrm{P}_{150} \mathrm{~K}_{75}\right)$. The affect of applied nutrients on leaf area revealed that maximum mean leaf area $369.99 \mathrm{~cm}^{2}$ was recorded in treatment $\left(\mathrm{N}_{150} \mathrm{P}_{100} \mathrm{~K}_{50}\right)$ followed by $\left(\mathrm{N}_{75} \mathrm{P}_{50} \mathrm{~K}_{25}\right)\left(365.99 \mathrm{~cm}^{2}\right)$ and the minimum mean average leaf area $362.36 \mathrm{~cm}^{2}$ was recorded in control $\mathrm{T}_{0}$ $\left(\mathrm{N}_{0} \mathrm{P}_{0} \mathrm{~K}_{0}\right)$. Among different clones the maximum average leaf area $384.07 \mathrm{~cm}^{2}$ was recorded in clone L-48/89 followed by clone PL-7 $\left(383.92 \mathrm{~cm}^{2}\right)$ and minimum leaf area $332.16 \mathrm{~cm}^{2}$ was recorded in PL-2 and the interaction between nutrient and clone was found significant. Maximum leaf area $419.28 \mathrm{~cm}^{2}$ was recorded in interaction between $\left(\mathrm{N}_{150} \mathrm{P}_{100} \mathrm{~K}_{50}\right)$ and clone $\mathrm{PL}-1$ and minimum average leaf area $298.42 \mathrm{~cm}^{2}$ was recorded in interaction between in control $\left(\mathrm{N}_{0} \mathrm{P}_{0} \mathrm{~K}_{0}\right)$ and clone PL-2.

Biomass of poplar clones in revealed that nutrients applied in different doses had significant effect on poplar biomass. Different recommended clones under study were recorded to be significant due to genotypes and their interaction effect with nutrients. The interaction effect showed that each clone has differential response to nutrient supplied in different combinations of $\mathrm{N}, \mathrm{P}$ and $\mathrm{K}$ treatment $\left(\mathrm{N}_{0} \mathrm{P}_{0} \mathrm{~K}_{0}\right)$, $\left(\mathrm{N}_{75} \mathrm{P}_{50} \mathrm{~K}_{25}\right),\left(\mathrm{N}_{150} \mathrm{P}_{100} \mathrm{~K}_{50}\right)$ and $\left(\mathrm{N}_{225} \mathrm{P}_{150} \mathrm{~K}_{75}\right)$ (Table 2). Further, among the nutrients treatments maximum biomass $3.15 \mathrm{~kg}$ was recorded in treatment $\left(\mathrm{N}_{150} \mathrm{P}_{100} \mathrm{~K}_{50}\right)$ followed by $\left(\mathrm{N}_{225} \mathrm{P}_{150} \mathrm{~K}_{75}\right)$ and $\left(\mathrm{N}_{75} \mathrm{P}_{50} \mathrm{~K}_{25}\right)(3.13 \mathrm{~kg})$ and the minimum mean biomass $3.09 \mathrm{~kg}$ was recorded in control $\left(\mathrm{N}_{0} \mathrm{P}_{0} \mathrm{~K}_{0}\right)$. Among different clones the maximum mean biomass $3.37 \mathrm{~kg}$ was recorded in clone L-48/89 followed by clone PL-6 (3.31 kg) and minimum mean biomass $2.81 \mathrm{~kg}$ was recorded in PL-1 and the interaction between nutrient and clone was also found significant. Maximum biomass $3.77 \mathrm{~kg}$ was recorded in interaction between $\left(\mathrm{N}_{150} \mathrm{P}_{100} \mathrm{~K}_{50}\right)$ and clone L-47/88 and minimum biomass $2.65 \mathrm{~kg}$ was recorded in interaction between $\left(\mathrm{N}_{75} \mathrm{P}_{50} \mathrm{~K}_{25}\right)$, and clone PL-1. DesRochers (2006) also reported the similar significant result of fertilization dosages of NPK on total biomass of Populus deltoides. Mohan (1992) also reported similar result in of effect of NPK fertilization on total biomass of Terminalia myriocarpa in nursery stage. Verlinden et al. (2013) reported that among the 12 genotype studied with genotype Hees showing the highest biomass production. Further, a strong interaction between clone (genotype) and fertilizer was observed for diameter, height and volume growth (Curlin, 1967). Such clonal differences may be the reflection of differential genetic potential of clones of favorable G×E interaction.

\section{Conclusion}

The application of fertilizer (nutrients) increases the growth parameters and nutrient uptake in leaf of ETPs when applied in combination (NPK in 3:2:1 ratio), resulted increase growth for most of the characters. It can be concluded from the present investigations that application of nutrient in combination increased growth and improved nutrient uptake in Populus deltoides leaves. Further, the result of present studies inferred that NPK in combination (3:2:1 ratio) should be used to increase the growth of Poplar.

\section{Acknowledgement}

We thank Head, Department of Forestry and Natural Resource, College of Agriculture, Punjab Agricultural University, Ludhiana, and field staff member, for their kind cooperation during the course of investigation.

\section{References}

Baker, J.B., Randall, W.K., 1975. Foliar nitrogen and potassium variation in cottonwood as affected by genetic and site factors. In (Editors USDA FS) Proceedings of the $12^{\text {th }}$ Lake States Forest Tree Improvement Conference, August 1975. General Technical Report NC- 26. St. Paul, MN: U.S. Dept. of Agriculture, Forest Service, North Central Forest Experiment Station 9, 106-111.

Barigah, T. S., Saugier, B., Mousseau, M., Guittet, J., Ceulemans, R., 1994. Photosynthesis, leaf area and productivity of 5 poplar clones during their establishment year. Annals of Forest Science, INRA/EDP Sciences, 1994, 51(6), 613-625

Bhardwaj, S.D., Sharma, G.S., Sharma, R.C., 1986. Effect of seed weight and nitrogen levels on growth and development of kachnar (Bauhinia variegata Linn) seedlings. Himachal Journal of Agricultural Research 12(1), 22-24.

Bilodeau-Gauthier, S., Pare, D., Messier, C., Belanger, N., 2011. Juvenile growth of hybrid poplars on acidic boreal soil determined by environmental effects of soil preparation, vegetation control, and fertilization. Forest Ecology and Management 261, 620-629.

Blackmon, B.G., 1977. Effects of fertilizer nitrogen on tree growth, foliar nitrogen and herbage in eastern cottonwood plantations. Soil Science American Journal 
41, 992-995.

Blackmon, B.G., White, E.H., 1972. Nitrogen fertilization increase cottonwood growth on old filed soil. USDA-FS, Southern Forest Station Research Note. S0 143, 5.

Brar, H.S., Katoch, P.C., 1980. Effect of different levels of nitrogen on growth characteristics of Populus deltoides (Marsh) under nursery conditions. Proc" National symp. Forest biomass, 299-303. HP KVK, Solan.

Chandra, J.P., Chauhan, S.K., Sharma, R., Garg, R.K., Singh, K., Saralch, H.S., 2011. Development of poplar based agroforestry system. Indian Journal of Ecology, 38, Special Issue, 11-14.

Curlin, J.W., 1967. Clonal differences in yield of Populus deltoides to nitrogen fertilization. Soil Science Society American Proceedings 31, 276-280.

Chauhan, S.K., Dhillon, W.S., Singh, N., Sharma, R., 2013. Physiological behaviour and Yield evaluation of Agronomic Crops Under Agri-horti-silviculture System. International Journal of Plant Research, 3(1), 1-8. DOI: 10.5923/j.plant.20130301.01

Chen, C.C., 1974. The influence of $\mathrm{N}$ concentration in nutrient solution on dry weight production of poplar rooted cuttings. Quarterly Journal Chinese Forestry 7(3), 47-57.

Denev, D.A., 1974. Effect of main nutrient elements (NPK) on growth of poplars. Govkostopanks Nauka 11(3), 12-26.

Deol, G.S., 1982. Manurial and isozymic studies on the male and female populations of Populus ciliata wall ex. Royle. M.Sc. Thesis, Himachal Pradesh Krishi Vishva Vidyalaya, Solan, India.

DesRochers, A., Van den Driessche, R., Thomas, B.R., 2006. NPK fertilization at planting of three hybrid poplar clones in the boreal region of Alberta. Forest Ecology and Management 232, 216-225.

Dhillon, A., Sangwan, V., Malik, D.P., Luhach, M.S., 2001. An economic analysis of poplar cultivation. Indian Forester 127(1), 86-90.

Dhillon, W.S., Chauhan, S.K., Jabeen, N., Singh, C., Singh, N., 2012. Growth Performance of Intercropping System Components and Nutrient Status of Soil under Horti-silvicultural System. International Journal of Environment and Resource 1(1), 31-38.

Durai, M.N., Ralhan, P.K., Sharma, R., Sing, A., Chauhan, S., 2009. Nutrient harvest through pruned material and whole tree in populus deltoides based agrisilviculture systems in central Punjab. Indian Forester 135, 17161723.

Fang, S.X., Baodong, L.J., 2008. Soil nutrient availability, poplar growth and biomass production on degraded agricultural soil under fresh grass mulch. Forest Ecology and Management 255, 1802-1809.

Gangoo, S.A., Mughal, A.H., Makay, A.S., 1997. Fertilizer response by two species of poplars on initial growth parameters. Indian Forester 199(3), 240-244.

Han, Si Ho., Young, An. Ji., Hwang Jaehong, Kim Se. Bin.,
Park Byung Bae., 2016. The effects of organic manure and chemical fertilizer on the growth and nutrient concentrations of yellow poplar (Liriodendron tulipifera Lin.) in a nursery system. Journal of Forest Science and Technology 12(3), 137-143.

Isaiah, M.A., 2013. Effect of inorganic fertilizers on the growth and nutrient composition of (Moringa oelifera). Journal of Emerging Trends in Engineering and Applied Sciences 4(42), 341-343.

Jobling, J., 1960. Establishment methods for poplars. Forest Research Community Land 43, 16.

Jones, N., Lal, P., 1989. Commercial poplar planting in india under agro-forestry system. The Commonwealth Forestry Review 68(1), 119-126.

Kumar, D., Singh, N.B., Rawat, G.S., Srivastava, S.K., Mohan, D., 1999. Improvement of Populus deltoides Bartr. ex Marsh in India-I. Present Status. Indian Forester 125(3), 245-263

Liani, A., 1978. N fertilizer trial in poplar nursery and determination of removal of minerals. Cellulosae Carta 29(5), 19-31.

Luna, R.K., Thakur, N.S., Kumar, V., 2011. Growth performance of twelve new clones of poplar in Punjab, India. Indian Journal of Ecolology 38, 107-109

Martin, J.W., Carter, M.C., 1967. Nitrogen improves growth of Populus deltoides nursery stock. USDA For Ser Tree Plant Notes 18(3), 24-26.

Mohan, S., 1992. Fertilizer responses on the growth and biomass of a common timber species of Arunachal Pradesh Terminalia myriocarpa (Hollack) seedlings. Indian Forester 117(11), 822-830.

Nakos, G., 1979. Fertilization of poplar clones in the nursery. Plant and Soil 53(1-2), 67-79.

Nelson, C.D., Tauer, C.G., 1987. Genetic variation on Juvenile characters of Populus deltoides Bartr from the southern great plains. Silvae Genetica 36, 216-221.

Panse, V.G., Sukhatme, P.V., 1989. Statistical methods for agricultural research workers. ICAR, New Delhi Pub and Information Division, ICAR, Krishi Anusandhan Bhawan, Pusa, New Delhi, 355.

Raina, R., Hara, S.S., Hara, V., Irland, L.C., 2011. Twentyfirst century forest plantations: development of agroforestry in Haryana. Journal of Resources, Energy, and Development 8, 2, 67-74.

Saravanakumar, R., Shanthinipriya, A., 2017. Effect of inorganic fertilizers and growth performance in Poplar tree (Populus deltoides). Research Journal of Agriculture and Forestry 5(9), 13-17.

Satoo, S., 1960. Some tests on the mineral nutrient of Populus davidiana. Journal of Northern For Soc Hokkaido 11, 21-22.

Sidhu, D.S., 1994. Evaluation of exotic and indigenous Populus deltoides Marsh clones for genetic diversification of agroforestry plantations. Journal of Tropical Forestry 
10(4), 263-270.

Sidhu, D.S., 1996. Genetic evaluation of Populus deltoides Marsh clones in nursery under Punjab conditions. Indian Journal of Forestry 19(1), 21-25.

Singh, R.P., Negi, D.V., 1996. Performance of exotic poplars under nursery conditions in Himachal Pradesh. Indian Forester 122(2), 122-127.

Singh, B., 2001. Influence of fertilization and spacing on growth and nutrient uptake in poplar (Populus deltoides) nursery. Indian Forester 127(1), 111-114.

Sivaprakash, R., Bongale, M., Dandin, U.D., Basavannah, S.B., Narayama Gowda, S.N., 2000. Nitrogen uptake and shoot yield in three improved varieties of mulberry (Morus india L.) under irrigated cultivation. Indian
Journal of Sericulture 39, 145-48.

Thakur, S., Sharma, K., Khurana, D.K., 1998. Nursery performance of selected new clones of Populus deltoides. Journal of Tree Science 17(1), 39-42.

Van den Driessche, R., 1999. First-year growth response of four Populus trichocarpaxPopulus deltoides clones to fertilizer placement and level. Canadian Journal of Forest Research 29, 554-562.

Verlinden, M.S., Brockx, L.S., Bulcke, Van Den, J., Van Aucker, J., Ceulemans, R., 2013. Comparative study of biomass determinants of 12 Poplar (Populus) genotypes in a high density Short rotation culture. Forest Ecology and Management 307(11), 101-111. 